\title{
Autoradiographic Studies of the Differential Incorporation of Glycine, and Purine and Pyrimidine Ribosides by Paramecium aurelia
}

\author{
BY H. M. BUTZEL, JUN. AND W. J. vAN WAGTENDONK \\ Veterans Administration Hospital and Department of Biochemistry, University \\ of Miami Medical School, Coral Gables, Florida, U.S.A.
}

(Received 17 July 1962)

\begin{abstract}
SUMMARY
Autoradiographs were prepared from organisms of Paramecium aurelia which were grown in an axenic medium to which one of the following compounds was added: [carboxy-14 $\mathrm{C}$ ]glycine, $\left[8^{-14} \mathrm{C}\right]$ adenosine, $\left[8^{14} \mathrm{C}\right]-$ guanosine, $\left[2-{ }^{14} \mathrm{C}\right]$ cytidine, $\left[{ }^{3} \mathrm{H}\right]$ thymidine, and $\left[{ }^{3} \mathrm{H}\right]$ uridine. Trichloroacetic acid extracts of organisms grown with the isotopically labelled glycine, adenosine and cytidine were prepared and the radioactivity found either in the protein or in the acid-soluble fractions was determined in a scintillation counter. $P$. aurelia was unable to incorporate glycine into the nucleic acids of the macronucleus; however, this compound was utilized in the formation of the cytoplasmic proteins. Thymidine was preferentially taken up by the macronucleus; uridine was found mainly in the cytoplasm. The other purine and pyrimidine ribosides were found both in the macronucleus and cytoplasm.
\end{abstract}

\section{INTRODUCTION}

Suggestive evidence that Paramecium aurelia might be unable to synthesize its purine and pyrimidine bases came from nutritional studies by Tarantola \& Van Wagtendonk (1959) who reported that this organism had an absolute growth requirement for ribosidic purines and pyrimidines. A similar requirement was earlier reported for the closely related species $\boldsymbol{P}$. multimicronucleatum (Johnson, 1952; Miller \& Johnson, 1957). Investigations by Soldo \& Van Wagtendonk (1961) of the nitrogen metabolism of $\boldsymbol{P}$. aurelia demonstrated the incorporation of some of the ribosidic purines and pyrimidines into nucleic acids and the failure of the incorporation of glycine into these compounds. The significance of the inability to utilize glycine as a precursor for purine synthesis was not emphasized. Autoradiographic techniques have also been utilized to study several facets of purine and pyrimidine metabolism in $P$. aurelia (Berech \& Van Wagtendonk, 1959, 1960, 1962; Kimball $\&$ Perdue, 1961). However, no comparative study of the fate of the purine precursor, glycine, and the preferential sites of the ultimate incorporation of purines and pyrimidines has been carried out.

\section{METHODS}

Stocks and their maintenance. Stock d-40 of syngen 1 and stock 51 of syngen 4 of Paramecium aurelia were examined in these experiments. Stock d-40 is a derived stock, homozygous for the recessive gene $m t^{\mathrm{I}}$, limiting it to the production of mating type I (Butzel, 1955). Stock 51 is a sensitive stock, homozygous for the 
gene $K$, which has lost the cytoplasmic particle, kappa (Sonneborn, 1946). Both stocks were maintained axenically at $27^{\circ}$ in the medium described by Soldo (1961).

The isotopically-labelled compounds, their specific activities and the dosage level in each medium are shown in Table 1. Glycine was obtained from The California Corporation for Biochemical Research, and the other compounds were purchased from Schwarz BioResearch Incorporated.

Table 1. Isotopically-labelled compounds used

\begin{tabular}{|c|c|c|}
\hline Isotopically-labelled compound & Specific activity & $\begin{array}{c}\text { Concentration } \\
\text { in medium } \\
\text { ( } \mu \text { curies } / \mathrm{ml} .)\end{array}$ \\
\hline$\left[\right.$ Carboxy $\left.{ }^{-14} \mathrm{C}\right] \mathrm{glycine}$ & $7.8 \mathrm{mc} . / \mathrm{mmole}$ & 10 \\
\hline$\left[8^{-14} \mathrm{C}\right]$ adenosine & $7 \cdot 2 \mu \mathrm{c} . / \mathrm{mg}$ & $3 \cdot 3$ \\
\hline$\left[8-{ }^{14} \mathrm{C}\right]$ guanosine & $15 \cdot 25 \mu \mathrm{c} . / \mathrm{mg}$. & $\mathbf{3} \cdot \mathbf{3}$ \\
\hline$[2-14 \mathrm{C}]$ cytidine & $4.0 \mu \mathrm{c} . / \mathrm{mg}$. & $\mathbf{3} \cdot \mathbf{3}$ \\
\hline$\left[{ }^{3} \mathrm{H}\right]$ thymidine & $3.0 \mathrm{c} . / \mathrm{mmole}$ & 25 \\
\hline$\left[{ }^{3} \mathrm{H}\right]$ uridine & $0.31 \mathrm{c} . / \mathrm{mmole}$ & 25 \\
\hline
\end{tabular}

Autoradiographs. The organisms were grown in the presence of each isotopically labelled compound for $\mathbf{3}$ to $\mathbf{5}$ days. The organisms were harvested by centrifugation, washed 4 times with a sterile baked lettuce infusion, adjusted to a $\mathrm{pH}$ value of 6.9 (Sonneborn, 1950), fixed to previously 'subbed' slides (Comar, 1955) and allowed to dry in air. Staining was by the Dippell-Chao modification of Delamater's basic fuchsin technique (Sonneborn, 1950). Eastman Kodak nuclear emulsion NB-2 was used and processed according to standard techniques (Pelc, 1947). Exposure times ranged from 10 to 14 days.

Assays for radioactivity of the protein and TCA-soluble fractions. Organisms were concentrated from the isotopically-labelled medium by centrifugation and washed 4 times in the sterile baked lettuce infusion. The final $1.0 \mathrm{ml}$. of centrifugate was homogenized and an equal volume of $10 \%(\mathrm{w} / \mathrm{v})$ trichloroacetic acid (TCA) added. The mixture was heated for $15 \mathrm{~min}$. at $90^{\circ}$, cooled, and then centrifuged at $0^{\circ}$ and $31,000 \mathrm{~g}$ for $10 \mathrm{~min}$. The supernatant fluid was poured off and saved. The sediment was extracted with an additional $2.0 \mathrm{ml}$. of TCA solution and recentrifuged. The two supernatant solutions were combined and extracted several times with diethyl ether in order to remove TCA. The sediment from the TCA extractions was dissolved in $1.0 \mathrm{ml}$. of $2 \%(\mathrm{w} / \mathrm{v}) \mathrm{NaOH}$ solution and heated in a boiling water bath for $15 \mathrm{~min}$. The radioactivity of the TCA soluble- and protein-fractions was determined in a Tricarb Scintillation Counter by adding $0.01 \mathrm{ml}$. of each preparation to the standard solute (Ott, 1958).

Determination of the presence of nucleic acid in the TCA-soluble fraction. Before counting the TCA-soluble fraction in the Tricarb Counter, the presence of nucleic acid was ascertained by determining the absorption spectrum at 254-260 $\mathrm{m} \mu$ in a Beckman model DU. spectrophotometer.

\section{RESULTS AND DISCUSSION}

The autoradiographs show that organisms grown in the presence of isotopicallylabelled glycine did not incorporate the label into the Feulgen-positive material of the macronucleus (Pl. 1, fig. 1); scintillation counts (Table 2) also showed that 
no radioactivity was present in the acid-soluble fraction derived from these organisms. In contrast, the labelling of the cytoplasm was very heavy and the protein fraction was highly radioactive. These findings indicate that the organisms were unable to use glycine for the formation of the purine bases of the nucleic acids, but that this amino acid was involved in protein synthesis. This is in accord with the observations by Soldo \& Van Wagtendonk (1961) and demonstrates that in Paramecium aurelia there is a metabolic block at the formation of glycinamide ribotide. These data therefore explain the long known need for preformed purine ribosides as essential nutrilites for this organism.

Table 2. Radioactivity of nucleic acid and protein fractions

\begin{tabular}{|c|c|c|}
\hline $\begin{array}{l}\text { Isotopically-labelled } \\
\text { compound }\end{array}$ & Fraction & $\begin{array}{c}\text { Average of eight } \\
10 \mathrm{~min} \text {. counts } / 0.01 \mathrm{ml} . \\
\text { sample } \pm \text { standard } \\
\text { deviation }\end{array}$ \\
\hline$\left[\right.$ Carboxy $\left.-{ }^{14} \mathrm{C}\right]$ glycine & $\begin{array}{l}\text { Protein } \\
\text { TCA-soluble }\end{array}$ & $\underset{-*}{53,081 \pm 322}$ \\
\hline$\left[8{ }^{14} \mathrm{C}\right]$ adenosine & TCA-soluble & $12,649 \pm 79$ \\
\hline$\left[8-{ }^{14} \mathrm{C}\right]$ guanosine & TCA-soluble & $38,664 \pm 101$ \\
\hline [2-14 C]cytidine & TCA-soluble & $9,610 \pm 116$ \\
\hline
\end{tabular}

The inability of Paramecium aurelia to utilize glycine makes this organism dependent on preformed purines. Tarantola \& Van Wagtendonk (1959) found that the free bases were not metabolized; therefore the purine ribosides were used in these experiments. Adenosine and guanosine were taken up by the organism, as shown by the autoradiographs (Pl. 1, figs. 2, 3). The label was found over the macronucleus and the cytoplasm. The radioactivity found in the TCA-soluble fraction (Table 2) confirms these autoradiographic observations. Adenine and guanine are constituents of ribonucleic acids and deoxyribonucleic acids, and the presence of the label in the macronucleus and the cytoplasm is to be expected. $\boldsymbol{P}$. aurelia thus appears to possess the enzymes responsible for the incorporation of the purine nucleosides into their DNA and RNA. Whether any precursors beyond glycinamide ribotide in the synthetic chain leading to the formation of the purine skeleton can be utilized by this organism remains to be investigated.

Each of the three isotopically-labelled pyrimidine ribosides had different ultimate sites of localization in the organism, in accordance with the differences in base composition found in deoxyribonucleic acid and ribonucleic acid. The label of the pyrimidine riboside, cytidine, which is common to both types of nucleic acid, was concentrated in the macronucleus as well as in the cytoplasm. No definite distinction can, however, be made between deoxyribonucleic acid and ribonucleic acid on the basis of autoradiographic data alone. This may also apply to the observations of Kimball \& Perdue (1961), who reported, on the basis of similar data, that cytidine is incorporated into the macronuclear ribonucleic acid alone. The label from the pyrimidine riboside, thymidine, which is incorporated only in DNA was concentrated in the macronucleus (Pl. 1, fig. 5); this is in accord with the findings of Berech \& Van Wagtendonk (1962). On the other hand, the label from uridine which was 
found only in RNA was heavily concentrated throughout the cytoplasm of the cell (Pl. 1, fig. 6).

It is of interest to note that each member of the Phylum Protozoa so far examined has shown an inability to synthesize purine bases. Tetrahymena pyriformis (Heinrich, Dewey \& Kidder, 1953), Paramecium aurelia (Soldo \& Van Wagtendonk, 1961), P. multimicronucleatum (Johnson 1952, Miller \& Johnson, 1957) among the ciliates and Trypanosoma mega (Boné \& Steinert, 1956) of the flagellates are dependent on an exogenous source of purine ribosides for nucleic acid synthesis. Of these, $T$. pyriformis, $\boldsymbol{P}$. aurelia, and Trypanosoma mega were unable to carry out the synthesis of glycinamide ribotide and it seems probable that the same metabolic block will be shown to be present in $P$. multimicronucleatum. It would seem more than a chance occurrence that of the four forms examined, all require purines as essential nutrilites. Perhaps it will be found that a biochemical distinction of the Phylum Protozoa will be the inability to form their nucleic acids from simple precursors, resulting in a dependence upon exogenous preformed purines for growth.

This work was supported by a research grant, E-3644, from the National Institutes of Health and a grant from the National Science Foundation (U.S.A.), G-14569. One of us (H. M. Butzel, Jun.) was a Special Post-doctoral Fellow of the U.S. Public Health Service on sabbatical leave from the Department of Biology, Union College, Schenectady 9, New York. The authors wish to acknowledge the technical assistance of Mr S. Reid and Mr W. Curtis.

\section{REFERENCES}

Berech, Jun., J. \& van Wagtendonk, W. J. (1959). Metabolic fate of macronuclear DNA after autogamy in Paramecium aurelia-an autoradiographic study. Science, $130,1413$.

Berech, Jun., J. \& van Wagtendonk, W. J. (1960). DNA turnover in Paramecium aurelia. Fed. Proc. 19, 313.

Berech, Jun., J. \& van Wagtendonk, W. J. (1962). An autoradiographic study of the macronuclear changes occurring in Paramecium aurelia during autogamy. Exp. Cell Res. 26, 360.

Bonk, G. J. \& STEINERT, M. (1956). Isotopes incorporated in the nucleic acids of Trypanosoma mega. Nature, Lond. 178, 308.

Butzex, JUn., H. M. (1955). Mating type mutations in variety 1 of Paramecium aurelia and their bearing upon the problem of mating type determination. Genetics, 40, 321.

Comar, C. L. (1955). Radioisotopes in Biology and Agriculture, 1st ed. New York: McGrawHill Book Company.

HeINRICH, M. R., Dewey, V. C. \& KidDer, G. W. (1953). Utilization of guanine by Tetrahymena geleii. J. Amer. chem. Soc. 75, 1741.

JoHnson, W. H. (1952). Further studies on the sterile culture of Paramecium. Physiol. Zoöl. 25, 10.

Kimball, R. F. \& Perdue, S. W. (1961). Autoradiographic studies of nucleic acid synthesis in Paramecium aurelia. Abstr. 1st Annual Meeting, Amer. Soc. Cell. Biology.

Miller, C. A. \& Johnson, W. H. (1957). Purine and pyrimidine requirement for Paramecium multimicronucleatum. J. Protozool. 4, 200.

Otт, D. G. (1958). Liquid Scintillation Counting, p. 101. New York: Pergamon Press.

Pesc, S. R. (1947). Autoradiograph technique. Nature, Lond. 160, 749.

Soldo, A. T. (1961). Cultivation of two strains of killer Paramecium aurelia in axenic medium. Proc. Soc. exp. Biol., N.Y. 105, 612. 

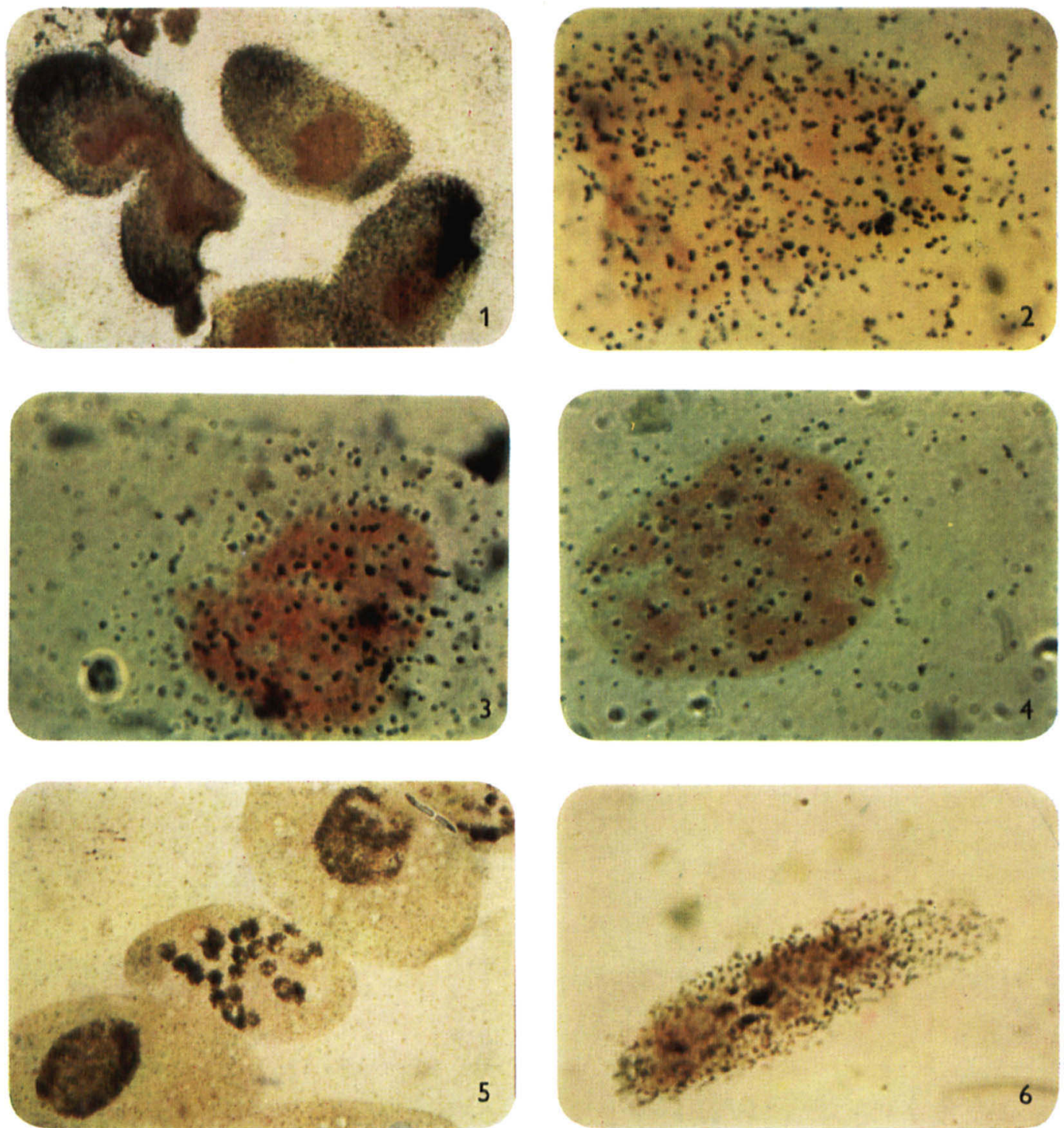

H. M. BUTZEL, JUN. AND W. J. VAN WAGTENDONK

(Facing p. 506) 
Soldo, A. T. \& van Wagtendonk, W. J. (1961). Nitrogen metabolism in Paramecium aurelia. J. Protozool. 8, 41.

Sonneborn, T. M. (1946). Experimental control of the concentration of cytoplasmic genetic factors in Paramecia. Cold. Spr. Harb. Symp. quant. Biol. 11, 236.

Sonneborn, T. M. (1950). Methods in the general biology and genetics of Paramecium aurelia. J. exp. Zool. 113, 87.

Tarantola, V. A. \& van Wagtendonk, W. J. (1959). Further studies of the nutritional requirement of Paramecium aurelia, variety 4, stock 51 (sensitive). J. Protozool. 6, 189.

\section{EXPLANATION OF PLATE}

Autoradiographs of Paramecium aurelia showing the distribution pattern of the incorporation of labelled glycine and labelled purines and pyrimidines.

Fig. 1. Organisms of stock 51 grown for 5 days in the presence of [carboxy ${ }^{14} \mathrm{C}$ ]glycine. One organism is in division. Note absence of grains over the stained macronucleus and the dense concentration over the cytoplasm. Magnification, $\times 126$ on film.

Fig. 2. Organism of stock $d-40$ after a similar period of growth in the presence of $\left[8-^{14} \mathrm{C}\right]$ adenosine. Only part of one organism is shown. Note grains over the macronucleus and the cytoplasm. Magnification, $\times \mathbf{2 5 0}$.

Fig. 3. An organism of stock $d-40$ grown in the presence of $\left[8-{ }^{-14} \mathrm{C}\right]$ guanosine. Only part of one organism is shown. Note similar distribution pattern of the label to the previous illustration. Magnification, $\times \mathbf{2 5 0}$.

Fig. 4. A stock $d-40$ organism grown in the presence of $\left[2-{ }^{14} \mathrm{C}\right]$ cytidine. Part of one organism is shown. The distribution of label is similar to that shown in $b$ and $c$. Magnification $\times 250$.

Fig. 5. Stock 51 organisms grown in the presence of $\left[{ }^{3} \mathrm{H}\right]$ thymidine. The middle organism is undergoing autogamy. Note dense concentration of label over the macronucleus and macronuclear fragments. Magnification $\times 126$.

Fig. 6. A stock 51 organism grown in the presence of $\left[{ }^{3} \mathbf{H}\right]$ uridine. The organism is in autogamy Note the dense concentration of label throughout the cytoplasm. Magnification, $\times 250$. 